\title{
Disability of enterprise employees in Chelyabinsk region of Russia due to poor environmental conditions
}

\author{
Alexandr Taradanov ${ }^{1, *}$, Vladislav Nevolin ${ }^{1}$, and Natalia Doldo ${ }^{1}$ \\ ${ }^{1}$ Chelyabinsk State University, 129, Br.Kashirinykh str., 454001, Chelyabinsk, Russia
}

\begin{abstract}
The research is based on analysis of the survey for identification of reasons for injuries and following disability of staff which was organized in November and December 2020. Experts-respondents were 415 employees of 258 enterprises and organization in Chelyabinsk region. As the main reason for disability was named mental outside of work injuries. The second reason is physical outside of work injuries. The $3^{\text {rd }}$ place in the list is physical injuries at work. The fourth reason is mental injuries at work. Thus, the working activity of respondents is 2.4 times less traumatic than outside of work activity. Experts named the reduction of attentiveness as the most valuable reason of injuries and following disability $(24.3 \%)$. Then follow the omission of technical control over the content of materials, equipment performance and tool quality $(19.2 \%)$, the omission of control over employees' behavior (19.1\%), risky behavior of employees at work $(18.6 \%)$, problems of the legislative framework for safety and health $(8.7 \%)$, no-fault incidents $(5.8 \%)$.
\end{abstract}

\section{Introduction}

The Chelyabinsk region is the industrial region in Russia and for that territory are relevant problems which are related to employees' disability. Understanding of the occupational safety and health in the region corresponds to global approaches that «Occupational health differs from occupational safety in that the duration of the impact that will arise, in which occupational health involves long-term exposure (routine activity) to hazardous condition while occupational safety deals with short-term exposure (accident or routine activity) with acute effects on human. Occupational accidents and illnesses also incurred two million deaths and decrease of $4 \%$ Gross Domestic Product (GDP) each year globally» [2].

Specialists name different factors as reasons for the disability. According to a theoretical model of occupational injuries, «various factors such as poor work conditions, tasks involving exposure to hazards, employment status (working part time or overtime), and individual characteristics such as demographics and the presence of a chronic disease, all combine to increase the risk of occupational injuries» [1].

\footnotetext{
*Corresponding author: taradanov@csu.ru
} 
Comparison researches of loss of working capacity are taking place in various areas of employment. «Respondents with jobs in the trades, transport or equipment operator were the most likely to have sustained occupational injuries. For CCHS (The Canadian Community Health Survey) 2001, 2007, 2009, 2010, 2012, and 2013, the highest odds of workplace injuries were observed for jobs in the trades, transport, or equipment operator sectors $(\mathrm{P}<0.001)$, whereas for CCHS 2011 and 2014, jobs in primary industry, processing, manufacturing, and utilities sectors were associated with the highest odds of occupational injuries.» [1].

Also researches analyze traumatic consequences of technical-technological changes, «Safety and health outcomes following the containerisation of an Italian port suggested that the employment and organisational changes that accompany containerisation may have created new risks, in particular the study finds psychosocial risk factors along with ergonomic risks that are qualitatively different from previous experiences» [5] [6].

«In other sectors OSH consequences associated with similar changes in the organisation of work and employment to those seen in container terminals are better-established. For example, establishments operating with a reduced and casualised workforce, with agency, contractor and directly employed workers engaged on the same worksite, are associated with increased vulnerability to accidents, injuries and ill-health [7], [8]. Intensified production demands and tight delivery schedules, (common in the loading and unloading of ships), are further associated with increased psycho-social risks health. These are known to not only cause forms of work-related ill-health such as stress and fatigue, but to also lead to increased risks of incidents that may cause injury or even fatalities» [6].

Other studies are dedicated to urban and gender characteristic of industrial injuries. «Work-disability outcomes of occupational injuries do differ when urban versus rural comparisons are made. A simple bivariate analysis indicated that highly urban residents experienced greater work disability, and multivariate investigations revealed that this observation was maintained after control for demographic differences» [11].

«A variety of psychosocial job stress measures, and workplace harassment have been associated with an increase in occupational injury in both men and women, although the specific stressors that contributed to those associations varied for men and women» [3].

A group of studies analyzes consequences of various occupational injuries. «This study showed that soft tissue injury without major anatomical disruption is the most common occupational injury in Hong Kong, although this injury is regarded as minor injury. A small percentage but large proportion of such injury could result in chronic work disability with work disability periods longer than 3 months. For example, $8.1 \%$ of workers with this minor injury require sick leave of more than 3 months. Unlike "severe" injuries such as fracture, the percentage of workers with this type of injury who develop chronic work disability is much higher. The percentage of the 312 cases that sustained fractures thus requiring more than 3 months' sick leave was $44.4 \%$. This duration of work disability may be considered acceptable or necessary for a normal healing process and rehabilitation time frame for fracture. When the number of cases that would have chronic work disability was counted, soft tissue injury contributed a higher proportion of cases (199 versus 139 cases).» [14].

The amount of studies, that analyze social and psychological consequences of occupational injuries and disability, is increasing. "A favourable psychosocial work environment has been associated with positive return to work outcomes after sickness absence, regardless of the health problem that initially led to the absence. Economic and social costs associated with the consequences of work-related stress, including sickness absence and disability, are not measured in many countries. When data is available, as is the case in Finland, Germany and the Netherlands, it shows an increase in absence and disability due to work-related stress and psychological health problems (Houtman, 2007: 
pp. 20-21, 25). Canadian studies have also shown mental health problems to be a significant source of work disability (Dewa et al., 2004, Gilmour and Patten, 2007, Park, 2008), and several studies have confirmed that mental health problems are attributable in whole or in part to stressful working conditions (Gilmour and Patten, 2007). In short, psychosocial hazards, including harassment, are clearly associated with disability and economic losses for individuals and organisations.» [4].

«Although occupational injury rates are on the decline, recovery from an injury, including time to return to work, remains a significant public health issue. Time away from the workplace not only affects a person's economic, psychological, and physical wellbeing, but also the economic and social health of society» [9-11].

«There is a very high rate of return to work following traumatic injury. Reduced return to work was seen in workers who were older, highlighting the need to enhance opportunities for re-education or retraining. Greater likelihood of returning to work was associated with lower symptoms of anxiety, depression and PTSD, which were all highly correlated. Perceived injustice significantly mediated the relationship between compensable injury and return to work, highlighting the need to address these psychological and functional outcomes synergistically to improve recovery» [12].

«At 3 months after the injury, nearly two-thirds (64\%) of respondents had returned to work. Of these, $83 \%$ were back full-time and $80 \%$ were back to their former job. Only $6 \%$ had different jobs, $6 \%$ had similar jobs, and the remaining $8 \%$ had a modified former job. Almost all of those who had returned to work $(92 \%)$ were with the same employer as at the time of injury. Of those who had not returned to work, one-third $(33 \%, 12$ of 36$)$ had made an attempt to return to work» [13].

\section{Methods}

Data were drawn from empirical research of causes of occupational injuries and the following disability, which was made in form of survey which was organized in November and December 2020. Experts-respondents were 415 employees of 258 enterprises and organization in Chelyabinsk region (random sample). The chosen sample with the size of population for sample surveys is 1620 people provide an error $5.0 \%$. 55.4\% of respondents are male, $44.6 \%$ - female. Respondents aged between $18-30$ were $43.9 \%$, respondents between 31 and 40 years accounted for 34.2 percent of all, $41-50$ years $-14.5 \%$, over the age of $50-7.5 \%$. Based on level of education respondents were divided into groups, and $36.1 \%$ respondents are with secondary education, $56.4 \%$ are with university education, $7.5 \%$ respondents are without professional education. According to work experience, the respondents were distributed as follows: less than 2 years $-20.5 \%$; $2-5$ years old $-26.0 \%$; $6-10$ years old $-24.3 \% ; 11-15$ years old $-14.7 \%$; over 15 years $-14.5 \%$.

Respondents also differ according to positions: $34.9 \%$ are simple workers, brigadiers $6.0 \%$; masters $-4.3 \%$; shift masters $-3.9 \%$; section managers $-5.1 \%$; foremen $-3.6 \%$; heads of divisions $-7.5 \%$; senior specialists (including occupational health and safety specialists) $-18.1 \%$; deputy directors $-5.5 \%$; chief engineers $-3.1 \%$; directors $-2.4 \%$. 10 respondents mentioned that they have 2 positions (in real work activity it is possible), and this situation defines the frame of the sum of percentages during the analysis at the level of $102.4 \%$.

Similarly, since respondents have personal work experience in different spheres, they gave a total of $182.9 \%$ of the answers and were distributed as follows: construction $-14.0 \%$; metallurgy - $15.2 \%$; mechanical engineering - $10.1 \%$; mining and ore processing $-7.5 \%$; oil and gas - 6.0\%; transport and transportation - 14.0\%; trade and service (including banks) 24.6\%; chemical industry - 10.1\%; agriculture - 5.8\%; fishing and fish farming - 3.1\%; timber harvesting and processing $-7.0 \%$; medicine and healthcare $-6.3 \%$; science and 
education - 10.8\%; "Power structures" (law enforcement, emergency services, military, sports) - 7.2\%; information technology ("computing") - $14.9 \%$; state and municipal administration $-12.8 \% .13 .5 \%$ respondents marked 'Other' as an answer.

\section{Results}

Respondents were asked to evaluate the impact and indicate the "weight" (in \%\%) of the causes of physical injuries at work, based on the list in the questionnaire. As a result, their answers were distributed as follows (Table 1):

Table 1. The distribution of respondents' answers about reasons of disability and injuries at work.

\begin{tabular}{|c|c|c|c|}
\hline \multirow[t]{2}{*}{$\begin{array}{l}\text { Question formulation and response options } \\
\text { Please indicate causes of occupational } \\
\text { injuries. The share of causes in percent: } \\
\text { the total should be } 100 \% \text {. }\end{array}$} & \multirow[t]{2}{*}{$\begin{array}{l}\text { All } \\
\text { respondents, } \\
\% \%\end{array}$} & \multicolumn{2}{|c|}{$\begin{array}{c}\text { Share of respondents, according } \\
\text { to the existence or absence of days } \\
\text { if disability because of } \\
\text { occupational injuries }\end{array}$} \\
\hline & & Existence & Absence \\
\hline 1 & 2 & 3 & 4 \\
\hline Amount of respondents $(\mathrm{n}=)$ & 415 & 159 & 256 \\
\hline Share in the sample $(\% \%)$ & 100.0 & 38.3 & 61.7 \\
\hline The reduction of attentiveness & 24.3 & 23.5 & 24.8 \\
\hline $\begin{array}{l}\text { The omission of technical control over the } \\
\text { content of materials, equipment performance } \\
\text { and tool quality }\end{array}$ & 19.2 & 20.2 & 18.7 \\
\hline $\begin{array}{l}\text { The omission of control over employees' } \\
\text { behavior }\end{array}$ & 19.1 & 19.9 & 18.6 \\
\hline Risky behavior of employees at work & 18.6 & 18.3 & 18.8 \\
\hline $\begin{array}{l}\text { Problems of the legislative framework for } \\
\text { safety and health }\end{array}$ & 8.7 & 8.2 & 8.9 \\
\hline No-fault incidents & 5.8 & 5.8 & 5.8 \\
\hline Other reasons & 4.3 & 4.1 & 4.4 \\
\hline Total & 100.0 & 100.0 & 100.0 \\
\hline
\end{tabular}

As the most valuable reason of injuries at work was named the 'The reduction of attentiveness' $(24.3 \%)$. Then follow the omission of technical control over the content of materials, equipment performance and tool quality (19.2\%), the omission of control over employees' behavior (19.1\%), risky behavior of employees at work (18.6\%), problems of the legislative framework for safety and health $(8.7 \%)$, no-fault incidents $(5.8 \%)$. Other reasons were mentioned by $4.3 \%$ respondents.

The following comments were made by the respondents, for specific reasons.

Table 2. The distribution of respondents' answers about disability because of occupational injuries, which were caused by the reduction of attentiveness.

\begin{tabular}{|c|c|c|c|}
\hline \multirow{2}{*}{$\begin{array}{c}\text { Question formulation and response } \\
\text { options } \\
\text { Please name causes of occupational } \\
\text { injuries at work }\end{array}$} & \multirow{2}{*}{$\begin{array}{l}\text { All } \\
\text { responde } \\
\text { nts, } \% \%\end{array}$} & \multicolumn{2}{|c|}{$\begin{array}{l}\text { Share of respondents, according to the } \\
\text { existence or absence of days if disability } \\
\text { because of occupational injuries }\end{array}$} \\
\hline & & Existence & Absence \\
\hline 1 & 2 & 3 & 4 \\
\hline Amount of respondents $(\mathrm{n}=)$ & 415 & 159 & 256 \\
\hline Share in the sample $(\% \%)$ & 100.0 & 38.3 & 61.7 \\
\hline $\begin{array}{l}\text { The reduction of attentiveness } 24.3 \% \text {, } \\
\text { includes: }\end{array}$ & 24.3 & 23.5 & 24.8 \\
\hline - alcohol and narcotic consequences & 5.5 & 4.9 & 5.8 \\
\hline - physical overwork & 4.9 & 4.7 & 5.0 \\
\hline - mental overwork & 4.3 & 4.3 & 4.3 \\
\hline
\end{tabular}




\begin{tabular}{|l|l|l|l|}
\hline - monotonous of the work & 2.4 & 2.4 & 2.5 \\
\hline - lack of personal experience of injuries & 2.4 & 2.5 & 2.4 \\
\hline - diverting the attention by others & 3.5 & 3.4 & 3.6 \\
\hline - other reasons & 1.3 & 1.2 & 1.3 \\
\hline
\end{tabular}

According to specific components 'The reduction of attentiveness' there is more or less noticeable difference in the most valuable factor of "alcohol and narcotic consequences" (5.8\% - of respondents without injuries against $4.9 \%$ of respondents who are with it). Analyzing of other factors shows that there is practically no difference between them ('physical overwork' 4.9\%; 'mental overwork' $4.3 \%$; 'diverting the attention by others' $3.5 \%$; 'monotonous of the work' $2.4 \%$; 'lack of personal experience of injuries' $2.4 \%$; 'other reasons' $1.3 \%)$.

Table 3. The distribution of respondents' answers about disability because of occupational injuries, which were caused by the omission of technical control over the content of materials, equipment performance and tool quality.

\begin{tabular}{|c|c|c|c|}
\hline \multirow[t]{2}{*}{$\begin{array}{l}\text { Question formulation and response } \\
\text { options } \\
\text { Please name causes of occupational } \\
\text { injuries at work }\end{array}$} & \multirow[t]{2}{*}{$\begin{array}{c}\text { All } \\
\text { respondents, } \\
\% \%\end{array}$} & \multicolumn{2}{|c|}{$\begin{array}{c}\text { Share of respondents, according to } \\
\text { the existence or absence of days if } \\
\text { disability because of occupational } \\
\text { injuries }\end{array}$} \\
\hline & & Existence & Absence \\
\hline 1 & 2 & 3 & 4 \\
\hline Amount of respondents $(\mathrm{n}=)$ & 415 & 159 & 256 \\
\hline Share in the sample $(\% \%)$ & 100.0 & 38.3 & 61.7 \\
\hline 1 & 2 & 3 & 4 \\
\hline $\begin{array}{l}\text { The omission of technical control over the } \\
\text { content of materials, equipment } \\
\text { performance and tool quality } 19.2 \% \text {, } \\
\text { includes: }\end{array}$ & 19.2 & 20.2 & 18.7 \\
\hline - lack of supervisors' qualification & 4.4 & 4.6 & 4.3 \\
\hline $\begin{array}{l}\text { - lack of controlling resources (people, } \\
\text { technical means of verification) }\end{array}$ & 4.6 & 4.9 & 4.4 \\
\hline $\begin{array}{l}\text { - lack of high technology hardware and } \\
\text { instruments }\end{array}$ & 5.8 & 6.0 & 5.6 \\
\hline $\begin{array}{l}\text { - the inefficiency of control under working } \\
\text { processes }\end{array}$ & 2.7 & 2.8 & 2.7 \\
\hline - other reasons & 1.7 & 1.9 & 1.6 \\
\hline
\end{tabular}

According to specific components 'The omission of technical control over the content of materials, equipment performance and tool quality' there is more or less noticeable difference in factors of 'lack of high technology hardware and instruments' $(5.6 \%$ - of respondents without injuries against $6.0 \%$ of respondents who are with it) and 'lack of controlling resources (people, technical means of verification)' (4.4\% of respondents without injuries against $4.9 \%$ of respondents who are with it). Analyzing of other factors shows that there is less valuable difference between them or no difference at all ('lack of supervisors' qualification' 4.4\%; 'inefficiency of controlling processes' $2.7 \%$; 'other reasons' $1.7 \%$ ).

Table 4. The distribution of respondents' answers about disability because of occupational injuries, which were caused by the omission of control over employees' behavior.

\begin{tabular}{|c|c|c|c|}
\hline $\begin{array}{c}\text { Question formulation and response } \\
\text { options }\end{array}$ & $\begin{array}{c}\text { All } \\
\text { Please name causes of occupational } \\
\text { injuries at work. }\end{array}$ & $\begin{array}{c}\text { Share of respondents, according to the } \\
\text { respondents, } \\
\text { existence or absence of days if disability } \\
\text { because of occupational injuries }\end{array}$ \\
\cline { 3 - 4 } & & Existence & Absence \\
\hline 1 & 2 & 3 & 4 \\
\hline
\end{tabular}




\begin{tabular}{|l|c|c|c|}
\hline Amount of respondents (n=) & 415 & 159 & 256 \\
\hline Share in the sample (\%\%) & 100.0 & 38.3 & 61.7 \\
\hline $\begin{array}{l}\text { The omission of control over employees' } \\
\text { behavior 19.1\%, includes: }\end{array}$ & 19.1 & 19.9 & 18.6 \\
\hline $\begin{array}{l}\text { - lack of controlling resources (people, } \\
\text { technical means of verification) }\end{array}$ & 5.1 & 5.2 & 5.0 \\
\hline - lack of supervisors' qualification & 4.6 & 4.7 & 4.6 \\
\hline $\begin{array}{l}\text { - the inefficiency of control under working } \\
\text { processes }\end{array}$ & 4.1 & 4.2 & 4.0 \\
\hline $\begin{array}{l}\text { - lack of opportunity for the objective } \\
\text { assessment of an employee's health }\end{array}$ & 3.6 & 4.0 & 3.4 \\
\hline - other reasons & 1.7 & 1.8 & 1.6 \\
\hline
\end{tabular}

The most noticeable difference is in the factor of 'lack of opportunity for the objective assessment of an employee's health' $-3.4 \%$ - of respondents without injuries against $4.0 \%$ of respondents who are with it. Analyzing of other factors shows that there is less valuable difference between them or no difference at all ('lack of controlling resources (people, technical means of verification)' $4.6 \%$; 'inefficiency of controlling processes' $4.1 \%$; 'other reasons' $1.7 \%$ ).

Table 5. The distribution of respondents' answers about disability because of occupational injuries, which were caused by the risky behavior of employees at work.

\begin{tabular}{|c|c|c|c|}
\hline \multirow[t]{2}{*}{$\begin{array}{l}\text { Question formulation and response options } \\
\text { Please name the causes of occupational } \\
\text { injuries at work. }\end{array}$} & \multirow[t]{2}{*}{$\begin{array}{l}\text { All } \\
\text { respondents, } \\
\% \%\end{array}$} & \multicolumn{2}{|c|}{$\begin{array}{c}\text { Share of respondents, } \\
\text { According to the existence or } \\
\text { absence of days if disability } \\
\text { because of occupational injuries }\end{array}$} \\
\hline & & Existence & Absence \\
\hline 1 & 2 & 3 & 4 \\
\hline Amount of respondents $(\mathrm{n}=)$ & 415 & 159 & 256 \\
\hline Share in the sample $(\% \%)$ & 100.0 & 38.3 & 61.7 \\
\hline $\begin{array}{l}\text { The risky behavior of employees at work } \\
18.6 \% \text {, includes: }\end{array}$ & 18.6 & 18.3 & 18.8 \\
\hline - pressure from managers & 4.0 & 3.7 & 4.2 \\
\hline $\begin{array}{l}\text { - willingness to save time, money, force or } \\
\text { valuable materials }\end{array}$ & 3.0 & 3.1 & 3.0 \\
\hline - willingness to earn more & 2.8 & 2.8 & 2.8 \\
\hline 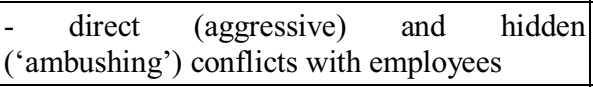 & 2.6 & 2.5 & 2.7 \\
\hline - following values (installations) & 1.9 & 1.9 & 2.0 \\
\hline $\begin{array}{l}\text { - intentional violation of safety test equipment } \\
\text { functioning }\end{array}$ & 1.8 & 1.8 & 1.8 \\
\hline - lack of personal experience of injuries & 1.4 & 1.4 & 1.4 \\
\hline - other reasons & 1.0 & 1.1 & 1.0 \\
\hline
\end{tabular}

According to specific components 'The risky behavior of employees at work' there is more or less noticeable difference only in the most valuable factor of 'pressure from managers' $(4.2 \%$ - of respondents without injuries against 3.7 of respondents who are with it). Analyzing of other factors shows that there is less valuable difference between them or no difference at all ('willingness to save time, money, force or valuable materials' $3.0 \%$; 'willingness to earn more' $2.8 \%$; 'following values (installations)' $1.9 \%$; 'intentional violation of safety test equipment functioning' $1.8 \%$; 'lack of personal experience of injuries' $1.4 \%$; 'other reasons' $1.0 \%$ ). 
Physical injuries at work are not the only reason for disability, that's other reasons also ware analyzed why during the research.

Table 6. The distribution of respondents' answers about reasons and amount of days of disability because of injuries at work or outside of it.

\begin{tabular}{|c|c|c|c|c|}
\hline \multirow{3}{*}{$\begin{array}{c}\text { Question formulation and } \\
\text { response options } \\
\text { Please, write how many days you } \\
\text { were disable during your work } \\
\text { experience because of : }\end{array}$} & \multicolumn{4}{|c|}{ Days of disability } \\
\hline & \multirow[b]{2}{*}{$\begin{array}{l}\text { Total days } \\
\text { of disability } \\
\text { in sample }\end{array}$} & \multicolumn{3}{|c|}{ Per one respondent } \\
\hline & & Average & $\begin{array}{c}\text { Have } \\
\text { physical } \\
\text { injuries at } \\
\text { work }\end{array}$ & $\begin{array}{l}\text { Without } \\
\text { physical } \\
\text { injuries } \\
\text { at work } \\
\end{array}$ \\
\hline 1 & 2 & 3 & 4 & 5 \\
\hline Physical injuries at work & 1340 & 3.2 & 8.4 & 0.0 \\
\hline Physical injuries outside work & 2030 & 4.9 & 9.7 & 1.9 \\
\hline Mental injuries at work & 1073 & 2.6 & 4.6 & 1.3 \\
\hline Mental injuries outside work & 3756 & 9.1 & 11.1 & 7.8 \\
\hline $\begin{array}{ll}\text { Total: } \\
\end{array}$ & 8199 & 5.0 & 8.5 & 2.8 \\
\hline
\end{tabular}

The main reason of the disability between respondents is 'mental injuries outside work': 3756 days of disability in sample and 9.1 days per one respondent in average. There are taking place events, as a result 'Everything slipped from respondents' hands'.

The next in the list are 'physical injuries outside work' (2030 days of disability and 4.9 days per one respondent).

At number 3 on the list are 'physical injuries at work' (1340 days of disability and 3.2 days per one respondent).

The 4th are 'mental injuries at work' (1073 days of disability and 206 days per one respondent).

Thus, labor activity of respondents is 2.4 less traumatic than their ordinary activity outside work: $(1340+1073) 2413$ days of disability because of injuries at work against $(2030+3756) 5786$ days of disability because of injuries outside work. At the same time, people, who have physical injuries at work, much often mentioned the existence of mental injuries than respondents without injuries.

The share of respondents with injuries rises with increasing of work experience.

Table 7. Shares of respondents, who have received and who haven't received injuries with following temporary disability, because of increasing of work experience.

\begin{tabular}{|c|c|c|c|c|}
\hline \multirow[t]{2}{*}{$\begin{array}{l}\text { Question formulation and response } \\
\text { options } \\
\text { Your work experience (in years) }\end{array}$} & \multicolumn{2}{|c|}{ All respondents } & \multicolumn{2}{|c|}{$\begin{array}{c}\text { Share of respondents, according } \\
\text { to the existence or absence of } \\
\text { days if disability because of } \\
\text { occupational injuries }\end{array}$} \\
\hline & Total & $\% \%$ & Existence & Absence \\
\hline 1 & 2 & 3 & 4 & 5 \\
\hline Amount of respondents $(\mathrm{n}=)$ & 415 & & 159 & 256 \\
\hline Share in the sample $(\% \%)$ & & 100.0 & 38.3 & 61.7 \\
\hline Less than 2 years & 85 & 20.5 & 10.7 & 26.6 \\
\hline $2-5$ years & 108 & 26.0 & 17.6 & 31.3 \\
\hline 6-10 years & 101 & 24.3 & 28.9 & 21.5 \\
\hline $11-15$ years & 61 & 14.7 & 18.2 & 12.5 \\
\hline Over 15 years & 60 & 14.5 & 24.5 & 8.2 \\
\hline
\end{tabular}

The distribution of respondents with less than 2 years of work experience is $26.6 \%$ (without injuries) against $10.7 \%$ (with injuries); with $2-5$ years $-31.3 \%$ against $17.6 \%$. Between respondents with 6-10 years of work experience the distribution changes to the 
opposite: $21.5 \%$ against $28.9 \%$; with $11-15$ years $-12.5 \%$ against $18.2 \%$; but the work experience over 15 years leads to the triple difference (8.2\% against $24.5 \%$ ).

Table 8. The distribution of respondents' answers about reasons of occupational disease because of existence-absence of disability caused by injuries at work.

\begin{tabular}{|c|c|c|c|}
\hline \multirow[t]{2}{*}{$\begin{array}{l}\text { Question formulation and response options } \\
\text { Please, write reasons of occupational diseases. } \\
\text { Indicate the share of each reason as a } \\
\text { percentage: the sum for all reasons should be } \\
100 \% \text {. }\end{array}$} & \multirow[t]{2}{*}{$\begin{array}{l}\text { All } \\
\text { respondents, } \\
\% \%\end{array}$} & \multicolumn{2}{|c|}{$\begin{array}{c}\text { Share of respondents, } \\
\text { according to the existence or } \\
\text { absence of days if disability } \\
\text { because of occupational } \\
\text { injuries }\end{array}$} \\
\hline & & Existence & Absence \\
\hline 1 & 2 & 3 & 4 \\
\hline Amount of respondents $(\mathrm{n}=)$ & 415 & 159 & 256 \\
\hline Share in the sample $(\% \%)$ & 100.0 & 38.3 & 61.7 \\
\hline Polluting production practices & 30.7 & 31.9 & 29.9 \\
\hline $\begin{array}{llll}\text { Working conditions: } & \text { noise, } & \text { vibration, } \\
\text { electromagnetic fields } & & \end{array}$ & 18.5 & 19.1 & 18.2 \\
\hline $\begin{array}{l}\text { Working conditions: lack of mobility, visual } \\
\text { workload }\end{array}$ & 13.3 & 13.2 & 13.4 \\
\hline Working conditions: physical overwork & 17.0 & 16.3 & 17.4 \\
\hline Working conditions: mental overwork & 14.4 & 13.5 & 14.9 \\
\hline Other reasons & 6.1 & 6.0 & 6.2 \\
\hline
\end{tabular}

The valuable difference at respondents' answers about reasons of occupational disease because of existence-absence of disability caused by injuries at work is absent. As the main reason $(30.7 \%)$ was named 'polluting production practices'. Then follow 'working conditions: noise, vibration, electromagnetic fields' (18.5\%), 'physical overwork' (17.0\%), 'mental overwork' (14.4\%) and 'working conditions: lack of mobility, visual workload' $(13.3 \%)$ with double reduction.

Male respondents are injuring to temporary disability more often female respondents.

Table 9. Share of respondents, who have received and who haven't received injuries with following temporary disability, based on their gender.

\begin{tabular}{|c|c|c|c|c|}
\hline \multirow{2}{*}{$\begin{array}{c}\text { Question formulation } \\
\text { and response options } \\
\text { Your gender }\end{array}$} & \multicolumn{2}{|c|}{ All respondents } & \multicolumn{2}{|c|}{$\begin{array}{l}\text { Share of respondents, according to the } \\
\text { existence or absence of days if disability } \\
\text { because of occupational injuries }\end{array}$} \\
\hline & Total & $\% \%$ & Existence & Absence \\
\hline 1 & 2 & 3 & 4 & 5 \\
\hline $\begin{array}{l}\text { Amount of respondents } \\
(\mathrm{n}=)\end{array}$ & 415 & & 159 & 256 \\
\hline Share in the sample (\%\%) & & 100.0 & 38.3 & 61.7 \\
\hline Male & 230 & 55.4 & 63.5 & 50.4 \\
\hline Female & 185 & 44.6 & 36.5 & 49.6 \\
\hline Total: & & & 100.0 & 100.0 \\
\hline
\end{tabular}

There is no valuable difference in group without disability because of occupational injuries between male and female respondents (50.4\% and $49.6 \%)$, but the amount of male respondents is doubled in comparison with female respondents in the group who experienced disability $(63.5 \%$ and $36.5 \%)$.

\section{Discussion}

As the most valuable reason of injuries at work was named the 'The reduction of attentiveness' $(24.3 \%)$. Then follow the omission of technical control over the content of 
materials, equipment performance and tool quality (19.2\%), the omission of control over employees' behavior (19.1\%), risky behavior of employees at work $(18.6 \%)$, problems of the legislative framework for safety and health (8.7\%), no-fault incidents $(5.8 \%)$. Other reasons were mentioned by $4.3 \%$ respondents.

The content of 'The reduction of attentiveness' (total is $24.3 \%$ ) is following: 'alcohol and narcotic consequences' - 5.5\%; 'physical overwork' - 4.9\%; 'mental overwork' $4.3 \%$; 'diverting the attention by others' $-3.5 \%$; 'monotonous of the work' $-2.4 \%$; 'lack of personal experience of injuries' $-2.4 \%$; 'other reasons' $-1.3 \%$.

The content of 'The omission of technical control over the content of materials, equipment performance and tool quality' (total is 19.2\%) is following: 'lack of high technology hardware and instruments' $-5.8 \%$; 'lack of controlling resources (people, technical means of verification)' $-4.6 \%$; 'lack of supervisors' qualification' $-4.4 \%$; 'inefficiency of controlling processes' $-2.7 \%$; 'other reasons' $-1.7 \%$.

The content of 'The omission of technical control over the content of materials, equipment performance and tool quality' (total is 19.2\%): 'lack of high technology hardware and instruments' - 5.8\%; 'lack of controlling resources (people, technical means of verification)' $-4.6 \%$; 'lack of supervisors' qualification' $-4.4 \%$; 'inefficiency of controlling processes' $-2.7 \%$; 'other reasons' $-1.7 \%$.

The content of 'The omission of control over employees' behavior' (total is 19.1\%) is following: 'lack of controlling resources (people, technical means of verification)' $-5.1 \%$; 'lack of supervisors' qualification' $-4.6 \%$; 'the inefficiency of control under working processes' $-4.1 \%$; 'lack of opportunity for the objective assessment of an employee's health' $-3.6 \%$; 'other reasons' $-1.7 \%$.

The content of 'The risky behavior of employees at work' (total is $18.6 \%$ ) is following: 'pressure from managers' $-4.0 \%$; ('willingness to save time, money, force or valuable materials' $-3.0 \%$; 'willingness to earn more' $-2.8 \%$; 'direct (aggressive) and hidden ('ambushing') conflicts with employees' $-2.6 \%$; 'following values (installations)' $-1.9 \%$; 'intentional violation of safety test equipment functioning' $-1.8 \%$; 'lack of personal experience of injuries' $-1.4 \%$; 'other reasons' $-1.0 \%$.

The main of respondent's disability 'mental injuries outside work': 3756 days of disability in sample and 9.1 days per one respondent in average.

The next in the list are 'physical injuries outside work' (2030 days of disability and 4.9 days per one respondent).

At number 3 on the list are 'physical injuries at work' (1340 days of disability and 3.2 days per one respondent).

The 4th are 'mental injuries at work' (1073 days of disability and 206 days per one respondent).

Thus, the working activity of respondents is 2.4 times less traumatic than their outwork activity: $1340+1073=) 2413$ days of disability at work against $(2030+3756=) 5786$ days of disability out of work. At the same time, people, who have physical injuries at work, much often mentioned the existence of mental injuries than respondents without injuries.

The share of respondents who were injured is increasing with the rising of work experience. The amount of respondents with less than 2 years of work experience and who haven't missed workdays because of disability is more than respondents who had disability (26.6\% against $10.7 \%$ ); with $2-5$ years $-31.3 \%$ against $17.6 \%$. Between respondents with 6-10 years of work experience the distribution changes to the opposite: $21.5 \%$ against $28.9 \%$; with $11-15$ years $-12.5 \%$ against $18.2 \%$; but the work experience over 15 years leads to the triple difference $(8.2 \%$ against $24.5 \%)$. Male respondents are injuring to temporary disability more often female respondents. 


\section{Conclusion}

Sorting of significances of reasons to injuries at work to temporary disability in decreasing order is defined: the reduction of attentiveness of staff; the omission of technical control over the content of materials, equipment performance and tool quality; the omission of control over employees' behavior; the risky behavior of employees at work; problems of the legislative framework for safety and health; no-fault incidents. However, the main reason for disability is mental injuries which were the result of activity outside of work, and then follow physical injuries outside of work, physical injuries at work, and mental injuries at work. The labor activity of staff is 2.4 times less traumatic than their nonworking activity.

\section{References}

1. B. Nowrouzi-Kia, A. Baig, A. Li, J. Casole, E. Chai, International Journal of Critical Illness and Injury Science 9(1), 29-35 (2019) DOI: 10.4103/IJCIIS.IJCIIS_43_18

2. W. Ying So, M.H. Hassim, S.I. Ahmad, R. Rashid, Process Safety and Environmental Protection 147, 103-114 (2021) DOI: 10.1016/j.psep.2020.09.015

3. Nakata, T. Ikeda, M. Takahashi, T. Haratani, M. Hojou, Y. Fujioka, N.G. Swanson, S. Araki, American Journal of Industrial Medicine 49(8), 658-669 (2006) DOI: 10.1002/ajim.20338

4. K. Lippel, M. Vézina, R. Cox. Safety Science 49(4), 582-590 (2011) DOI: 10.1016/j.ssci.2010.04.011

5. Fabiano, F. Currò, A.P. Reverberi, R. Pastorino, Safety Science 48(8), 980-990 (2010) DOI: 10.1016/j.ssci.2009.08.007

6. A. Walters, E. Wadsworth, Marine Policy 124 (2021) DOI: 10.1016/j.marpol.2020.104374

7. M. Quinlan, P. Bohle, International Journal of Health Services 38(3), 489-523 (2008) DOI: $10.2190 /$ HS.38.3.g

8. M. Quinlan, C. Mayhew, P. Bohle, International Journal of Health Services 31(2), 335414 (2001) DOI: 10.2190/607H-TTV0-QCN6-YLT4

9. A. Weil, American Journal of Industrial Medicine 40(4), 418-437 (2001) DOI: 10.1002/ajim. 1114

10. A.E. Dembe, American Journal of Industrial Medicine 40(4), 403-417 (2001) DOI: 10.1002/ajim.1113

11. A.E. Young, R. Wasiak, B.S. Webster, R.G.F. Shyne, Scandinavian Journal of Work, Environment and Health 34(2), 158-164 (2008) DOI: 10.5271/sjweh.1217

12. M.J. Giummarra, P.A. Cameron, J. Ponsford, L. Ioannou, S.J. Gibson, P.A. Jennings, N. Georgiou-Karistianis, Journal of Occupational Rehabilitation 27(2), 173-185 (2017) DOI: $10.1007 / \mathrm{s} 10926-016-9642-5$

13. I.Z. Schultz, J. Crook, J. Berkowitz, R. Milner, G. R. Meloche, Journal of Occupational Rehabilitation 15, 365-376 (2005) DOI: 10.1007/s10926-005-5943-9

14. A.S.K. Cheng, L.K. Hung, Hong Kong Journal of Occupational 17(2), 45-53 (2007) DOI: $10.1016 / \mathrm{S} 1569-1861(08) 70003-2$ 